\title{
Description of the Immatures of Scaptocoris carvalhoi Becker (Hemiptera: Cydnidae)
}

\author{
LM Vivan ${ }^{1}$, C Nardi $^{2}$, J Grazia $^{3}$, JMS Bento $^{4}$ \\ ${ }^{1}$ Fundação MT, Rondonópolis, MT, Brasil \\ ${ }^{2}$ Univ Estadual do Centro-Oeste, Guarapuava, PR, Brasil \\ ${ }^{3}$ Univ Federal do Rio Grande do Sul, Porto Alegre, RS, Brasil \\ ${ }^{4}$ Univ de São Paulo, ESALQ/USP, Piracicaba, SP, Brasil
}

\section{Keywords}

Burrower bugs, descriptive morphology, nymphs, morphology, soil pests

\section{Correspondence}

C Nardi, Univ Estadual do Centro-Oeste, CEP 85040-080, Guarapuava, PR, Brasil; cnardi@unicentro.br

Edited by Roberto A Zucchi - ESALQ/USP

Received 27 February 2012 and accepted 7 February 2013

Published online 21 March 2013

(C) Sociedade Entomológica do Brasil 2013

\begin{abstract}
Nymphs and adults of the burrower bug Scaptocoris carvalhoi Becker feed on vegetal sap of their host plants through the roots, and little is known on the morphology and biology of its immature stage. Therefore, we aimed to characterize the immatures of $S$. carvalhoi by describing the egg and the morphology of each instar. Eggs of $S$. carvalhoi have a smooth chorion surface without visible micropylar processes. The presence of five instars was confirmed by the coefficient of determination $\left(R^{2}>0.95\right)$ and by the growth constant ( $K$ between 1.2 and 1.6). Nymphs have an elliptical body and fossorial scythe-like forelegs. The tarsi are absent as in adults, and the prototarsal insertion region becomes visible only in the fourth instar. Nymphs from first to fourth instar of $S$. carvalhoi showed the presence of $1+1$ trichobothria in urosternites III to VII, close to the anterior margin and inside the spiracles; besides these trichobothria, fifth instars presented $1+1$ pre-trichobothria in urosternites III to V located posteriorly, almost in the row of spiracles close to the posterior margin of the urosternites. This is the first detailed morphological record of immatures belonging to Scaptocoris.
\end{abstract}

\section{Introduction}

The main species of Scaptocoris Froeschner occurs from the Nearctic region to the south of the Neotropical region. In these regions, this genus is represented by seven species, three of which occur in cultivated plants, Scaptocoris buckupi Becker, Scaptocoris carvalhoi Becker, and Scaptocoris castanea Perty (Froeschner 1960, Becker 1996, Grazia et al 2004).

Scaptocoris carvalhoi is one of the most important soil pest species in Brazil and is associated with different plants, mainly grasses. As with other Scaptocorini species, it is characterized by its underground mode of life and by the expanded tibiae adapted for digging (Froeschner 1960, Becker 1967). After nomenclatural and taxonomic arrangements made by Grazia et al (2004), S. carvalhoi was defined as senior synonym to Atarsocoris brachiariae Becker, whose adults have reduced tarsi or tarsal insertion in fore and mid-tibiae, and notably elongated distal tubercles in corbiculum (Becker 1967, Grazia et al 2004). Recently, Nardi et al (2008) reported that this species presents wing dimorphism, with migrant macropterous and non-migrant brachypterous forms.

Studies on burrower bugs are rare and the lack of information, mainly on their biology and behavior, limits the research and development of management techniques for this insect. Up to now, the main studies on S. carvalhoi were related to the adult stage, but knowledge on immatures is also important for the characterization of their biology and establishment of laboratory rearing. The morphological study of immatures may also be useful to differentiate Scaptocoris species, widening the possibilities for their recognition. Thus, we describe in here the morphological characteristics of immatures of $S$. carvalhoi in order 
to provide information to support the development of future basic and applied research.

\section{Material and Methods}

Insects

Specimens of S. carvalhoi were collected from excavated soil in a soybean field (Glycine max) from October 2009 to February 2010 and in a Brachiaria field (Brachiaria sp.) from February to September 2010, in Primavera do Leste, MT, Brazil ( $\left.14^{\circ} 48^{\prime} 59.5^{\prime \prime} \mathrm{S}, 54^{\circ} 11^{\prime} 04.8^{\prime \prime} \mathrm{W}\right)$. The specimens collected were identified according to the diagnostic traits of $S$. carvalhoi, such as the absence of tarsi, characteristics of the head, and shape of the clypeus (Becker 1967, Grazia et al 2004).

The eggs used for morphometry were obtained from females of $S$. carvalhoi collected in the field and maintained in laboratory conditions. Parts of these eggs $(N=10)$ were collected after oviposition in the soil and parts $(N=260)$ were collected directly from the reproductive tract of adult females following dessication. Females were dissected by a lateral incision in their abdomen and all eggs in the common oviduct were collected. This procedure was adopted due to the great difficulty in finding eggs in the field and the low rate of oviposition under laboratory conditions. In order to guarantee a reliable description, eggs obtained from the reproductive tract were previously compared to those from the field and no apparent differences were identified.

The morphological analysis of nymphs was done using $70 \%$ ethanol-preserved specimens of different sizes randomly collected in the field $(N=478)$. To ensure the presence of first instars in the sample, eggs laid by females in laboratory were maintained under controlled conditions $\left(23 \pm 2^{\circ} \mathrm{C} ; 60 \pm 10 \% \mathrm{RH} ; 14 \mathrm{~L}: 10 \mathrm{D}\right)$ until eclosion $(N=10)$. First instars were analyzed immediately after hatching, while the remaining instars obtained in the field were later processed.

\section{Morphology and morphometry}

Nymphs of $S$. carvalhoi $(N=478)$ were separated by morphotype according to the characteristics described for Cydnidae (García \& Bellotti 1980, Sites \& McPherson 1982, Stehr 1991) and by other Pentatomoidea (Grazia \& Frey-daSilva 2001, Schwertner et al 2002) based on the degree of development of the pteroteca.

Eggs and nymphs were measured with a wide angle micrometric eyepiece (WF $10 \times / 23 \mathrm{~mm}$ ) with linear and cross graduation $(0.1 / 14 \mathrm{~mm})$ for stereomicroscope (Motic, SMZ 168). Egg length and egg width were recorded, and the presence of micropylar processes was registered. For the nymphs, we assessed the body length, head length, pronotum length and width, scutellum length, abdomen length and width, and head width. All measurements of length were done along the median longitudinal line, while the width measurements were taken along the widest transversal line over the body. Pigmentation and shape features of immatures were analyzed under a stereomicroscope and described according to the terminology of Becker (1967).

Illustrations were made from specimens preserved in alcohol $70 \%$ using a camera lucida mirror type connected to a stereo microscope. Voucher specimens were deposited at the "Coleção Entomológica do Departamento de Zoologia da Universidade Federal do Rio Grande do Sul."

\section{Statistical analysis}

Morphometric data of the nymphs of $S$. carvalhoi were analyzed by the determination index $\left(R^{2}\right)$ and growth constant $(K)$ (Dyar 1890) using of Microsoft Office Excel $2007^{\circledR}$. These parameters were used to confirm the hypothesis of the existence of five instars according to Parra \& Haddad (1989).

\section{Results}

The initial morphological evaluation of nymphs of $S$. carvalhoi based on the development of the pteroteca enabled the identification of five morphological groups which supported the hypothesis of the existence of five instars. For all parameters assessed, the morphometric analysis resulted in a determination index $\left(R^{2}\right)$ greater than 0.95 . Furthermore, the growth constant $(K)$ remained between 1.2 and 1.6 (Table 1).

From the separation of nymphs in five instars, it became possible to describe $S$. carvalhoi immatures according to their shape and color:

Egg. Elliptical; height, $1.6 \pm 0.21 \mathrm{~mm}$; width, $0.9 \pm 0.12 \mathrm{~mm}$; color uniform, whitish-yellow; chorion surface smooth, aero-micropylar processes absent

First instar (Fig 1a and Table 1). Body elliptical, color uniform whitish-yellow. Head elliptical, flat at apex, lateral margins slightly darkened; dorsal surface with low transversal grooves reaching distal third; ocelli absent; tylus longer than juga, wide at apex; rostrum four-segmented covered by sparse setae, longer on dorsal surface of segment II; antennae four-segmented, segments I to III almost cylindrical, segment IV fusiform longer than segments II and III combined, segment III the shortest. Proportion of antennal segments: $|\approx \||>|||<| V$. Thorax mostly whitish-yellow, pronotum longer and darker than meso- and metanotum; tibia of 
Table 1 Morphometrical data $(X \pm S D$ ) (in millimeter) and statistical parameters $(K=$ growth constant, $p=$ significance value, $R^{2}=$ determination index) of immatures of Scaptocoris carvalhoi $(n=480)$.

$A L$ abdomen length, $B L$ body length, $H L$ head length, $S L$ scutellum length, $P L$ pronotum length, $A W$ abdomen width, $H W$ head width, $P W$ pronotum width.

\begin{tabular}{|c|c|c|c|c|c|c|c|c|}
\hline \multirow[t]{2}{*}{ Body part } & \multicolumn{5}{|c|}{ Measurements (mean $\pm S D)(m m)$, instar } & \multirow[t]{2}{*}{$K$} & \multirow[t]{2}{*}{$p$} & \multirow[t]{2}{*}{$R^{2}$} \\
\hline & First & Second & Third & Fourth & Fifth & & & \\
\hline AL & $1.07 \pm 0.08$ & $1.26 \pm 0.20$ & $1.79 \pm 0.41$ & $2.32 \pm 0.40$ & $2.47 \pm 0.23$ & 1.23 & 0.003 & 0.99 \\
\hline BL & $2.28 \pm 0.10$ & $2.52 \pm 0.24$ & $3.05 \pm 0.32$ & $4.28 \pm 0.35$ & $5.22 \pm 0.23$ & 1.23 & 0.004 & 0.99 \\
\hline $\mathrm{HL}$ & $0.46 \pm 0.05$ & $0.46 \pm 0.13$ & $0.66 \pm 0.08$ & $0.80 \pm 0.15$ & $1.02 \pm 0.13$ & 1.23 & 0.007 & 0.98 \\
\hline SL & $0.21 \pm 0.02$ & $0.31 \pm 0.04$ & $0.53 \pm 0.10$ & $0.82 \pm 0.15$ & $1.26 \pm 0.12$ & 1.57 & 0.02 & 0.96 \\
\hline $\mathrm{PL}$ & $0.42 \pm 0.03$ & $0.44 \pm 0.08$ & $0.63 \pm 0.10$ & $1.00 \pm 0.11$ & $1.11 \pm 0.15$ & 1.29 & 0.005 & 0.99 \\
\hline AW & $1.29 \pm 0.10$ & $1.64 \pm 0.18$ & $2.00 \pm 0.25$ & $2.75 \pm 0.35$ & $3.29 \pm 0.31$ & 1.26 & 0.003 & 0.99 \\
\hline HW & $0.46 \pm 0.02$ & $0.47 \pm 0.07$ & $0.58 \pm 0.07$ & $0.75 \pm 0.07$ & $1.00 \pm 0.07$ & 1.22 & 0.005 & 0.99 \\
\hline PW & $0.99 \pm 0.07$ & $1.24 \pm 0.18$ & $1.58 \pm 0.18$ & $2.08 \pm 0.23$ & $2.66 \pm 0.18$ & 1.28 & 0.005 & 0.99 \\
\hline
\end{tabular}

anterior and median legs not showing the area of tarsal insertion; legs slightly darker than body, with long and sparse light brown setae, denser at tibiae; anterior legs fossorial, tibiae scythe-like, whitish-yellow, apex darkened, covered with sparse setae, denser at ventral surface; median legs with flat tibiae, fine setae covering ventral surface of femur, longer and tougher setae on dorsal and ventral surfaces of tibiae; posterior legs short and thickened, femur rough and strongly convex laterally, tibiae cylindrical, expanding toward apex, corbiculum in " $U$ " distal surface truncate, marginal tubercles flat, distal tubercles elongate placed in a single and irregular row nearer lateral margin of, from base to median region of corbiculum. Abdomen entirely whitishyellow, lateral margins with sparse hairs, denser at apex; the three pairs of dorsal abdominal scent gland openings are placed between abdominal terga III-IV, IV-V, and V-VI, first pair almost hyaline, second and third pairs slightly darkened; spiracles on urosternites II to VIII; trichobothria (1+1) from urosternites III to VII, placed medially to spiracles near anterior margins of each segment.

Second instar (Fig 1b and Table 1). Body elliptical, color whitish-yellow with light brown areas. Head elliptical, lateral margins more sclerotized. Thorax whitish-yellow with symmetrical light brown spots; mesonotum posterior margin convex at middle denoting the scutellum formation; legs from whitish-yellow to light brown. Abdomen whitish-yellow with darker spots along median line and lateral margins. Spiracles, trichobothria, and other characteristics as in first instar.

Third instar (Fig 1c and Table 1). Body ovate, color whitishyellow with light brown areas. Head sloping ventrally, with seven transversal grooves, margins darkened from fourth groove. Thorax darker than the remaining body; pronotum with light brown irregular spots; mesonotum and metanotum posterior margins with lateral slight projections denoting the wing pads formation; metathorax shorter than pro- and mesothorax. Abdomen globose, mostly whitish-yellow. Other characteristics as described for previous instars.
Fourth instar (Fig 1d and Table 1). Body ovate, strongly convex, color whitish-yellow with light brown areas. Head light brown with transversal curved grooves from apex to basal third, near eyes; tylus longer than juga, with apex almost twice as wide as an eye diameter; ocelli present. Thorax light brown; pronotum subdivided in two lobes, the anterior with darker, small spots irregularly distributed; lateral projections on posterior margins of meso- and metanotum well defined denoting the wing pad formation. Abdomen with median dorsal plates juxtaposed the posterior margins of tergites III-V; urotergites VII-IX with longer and denser setae; posterior margins of urosternites with a row of setae. Other characteristics as described for previous instars.

Fifth instar (Fig 1e and Table 1). Head with transversal curved grooves surpassing the line of the eyes. Thorax and legs with varying color from whitish-yellow to light brown. Scutellum well developed on mesonotum. Wing pads well developed on meso- and metanotum, reaching or surpassing posterior margin of urotergites II or III. Abdomen urosternites III to $\mathrm{V}$ with $1+1$ pre-trichobothria, additional to trichobothria, placed near posterior margins of the segments, posteriorly and almost along the spiracles row. Abdomen with sparse setae on median ventral surface, denser at apex (segments VII-IX), surrounding anal tube. Other characteristics as described for previous instars.

\section{Discussion}

The importance of identifying immature insects and the increased need for morphological and biological studies of heteropterans have been recently emphasized by different authors (Martins \& Campos 2006, Matesco et al 2009). These studies tend to not only increase knowledge on the target species, but also bring solutions to many of the problems related to taxonomy or applied entomology (Decoursey \& Esselbaugh 1962, Richter 1972, Brailovsky et al 1992). 
A
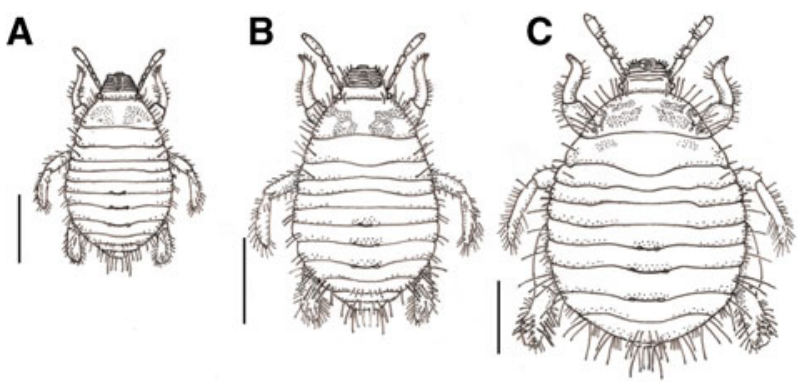

D
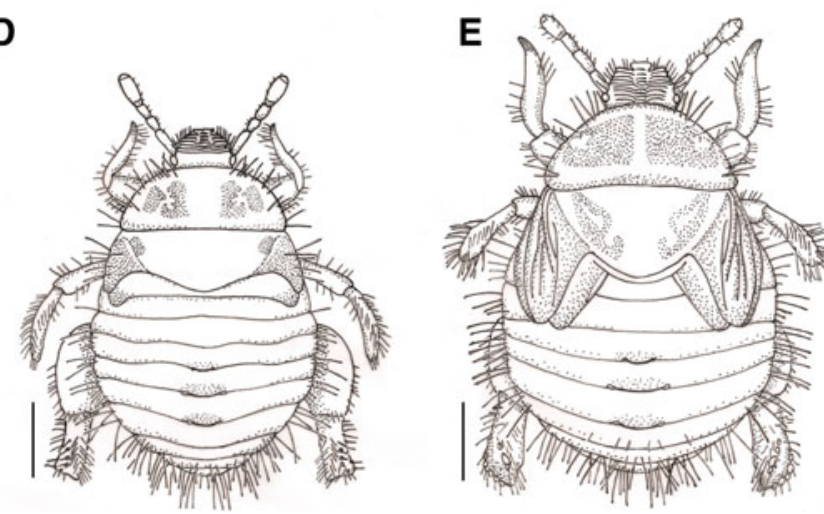

Fig 1 Immature stages of Scaptocoris carvalhoi. (A) First instar; (B) Second instar; (C) Third instar; (D) Fourth instar; (E) Fifth instar (illustrated by Patricia Milano) Scale bar $=1 \mathrm{~mm}$.

The lack of research on the forms of young Cydnidae is evident since few species had their immatures described in detail. Immature Amnestinae were studied by Froeschner (1960) and Mayorga \& Cervantes (2001), who emphasized that many of these insects do not present fossorial legs as it commonly occurs in other species in this family. For Sehirinae, the first descriptions were done for immatures of Tritomegas bicolor (Linnaeus) (as Sehirus bicolor) (Southwood 1949, Southwood \& Hine 1950, Stokes 1950, Paul 1953). Later, McDonald (1968) and Sites \& McPherson (1982) described the immatures of Sehirus cinctus albonotatus Dallas and Sehirus cinctus cinctus (Palisot de Beauvois), respectively, both North American subspecies. Cobben (1968) briefly characterized the egg of Adomerus biguttatus (Linnaeus) (as Sehirus biguttatus), mentioning that as in other members of the subfamily, this species protects its egg clusters which are deposited onto the soil. In turn, immature Cydnidae were described by Garcia \& Bellotti (1980), who stressed the presence of tarsi in the three pairs of legs and tibia with spines in Cyrtomenus bergi Froeschner. For Cephalocteinae, only two descriptions of immatures were done: one by Ayyar (1930), who briefly characterized the eggs and the first instar of Schiodtella tabulata (Schiödte) (as Stibaropus tabulate), and another by Lis (1991), who characterized the fifth instar of Schiodtella secunda Lis.
The tarsi are absent in S. carvalhoi and the prototarsal insertion can be visualized from the fourth instar and on. According to the taxonomy proposed by Grazia et al (2004), the presence of prototarsal insertion in adults is one of the characteristics that differentiate Scaptocoris from Atarsocoris. Considering that the tarsal insertion is evident also in immatures of S. carvalhoi, this characteristic can be of great importance for differentiating insects in this life stage. Since other Scaptocoris species have well developed tarsi in the adult stage, we suggest that additional studies should be done in order to verify the presence of tarsi or tarsal insertions in immatures to enable species recognition at the immature stage.

The trichobothria observed in segments III to VII near the anterior margin interiorly to the spiracles of $S$. carvalhoi may play a sensorial role as described in other body regions (head, legs, and abdomen) of Pentatomoidea (Schaefer 1975, Cobben 1968, Schuh \& Slater 1995). In Cephalocteinae, the distribution of trichobothria in adults is one of the main characteristics used to define a few genera and is considered an important trait for phylogeny and taxonomy (Lis \& HoholKilinkiewicz 2001). According to Lis \& Kilinkiewicz (2001), there are three different types of trichobothria distribution in Cephalocteinae adults on abdominal segments III to VII. According to these authors, fifth instars of Scaptocoris australis L. present these structures with the same distribution as the adults. We observed that the trichobothria of $S$. carvalhoi are already evident in first instars. From the first to the fourth instars, $1+1$ trichobothria were observed anteriorly in urosternites III to VII, and 1+1 pre-trichobothria were observed in urosternites III to $\mathrm{V}$ posteriorly to the spiracles in fifth instars. Considering that $S$. carvalhoi is an underground insect with intense physical contact with soil, it is possible that trichobothria have an important role in sensorial perception and in the way these insects move. According to Keil (1997), these structures may be involved in the perception of air flow or sound as demonstrated in other soil organisms (Haupt 1970, 1978, Bareth \& Juberthie-Jupeau 1986), including heteropterans (Draslar 1973).

Biological studies on burrower bugs are very limited especially due to the difficulties in rearing and breeding these insects in laboratory conditions. Sales Junior \& Medeiros (2001) described the bioecology of the burrower bug S. carvalhoi and estimated the duration of the egg, nymph, and adult stages, but their biological data are only an estimate and were obtained from field observation. Consequently, the present morphological study contributes to the knowledge of the biology and laboratory rearing of $S$. carvalhoi especially in instar recognition is necessary. Furthermore, our data may help in the recognition of organisms collected from soil as well as support future comparative studies with other species of this genus. 
Acknowledgments Special thanks are due to CNPq/FAPESP and "INCT-Semioquímicos na Agricultura" for financial support and for the PhD fellowship granted to LMV (CNPQ no. 152291/2007-5).

\section{References}

Ayyar PN (1930) A note on Stibaropus tabulata, Schiö. (Hem., Pent.), a new pest of tobacco in South India. Bull Entomol Res 21/22: 29-31

Bareth C, Juberthie-Jupeau L (1986) Ultrastructure des trichobothries de l'antenne de Campodea kervillei Denis et Plusio campacognata Condé (Apterygota: Diplura: Campodeidae). Int J Insect Morphol Embryol 15:429-438

Becker M (1967) Estudos sobre a subfamília Scaptocorinae na região neotropical (Hemiptera: Cydnidae). Arq Zool 15:291-325

Becker M (1996) Uma nova espécie de percevejo-castanho (Heteroptera: Cydnidae: Scaptocorinae) praga de pastagens de Centro-Oeste do Brasil. An Soc Entomol Bras 25:95-102

Brailovsky H, Cervantes L, Mayorga C. (1992) Hemiptera: Heteroptera de México XLIV - Biología, estadios ninfales y fenología de la tribu Pentatomini (Pentatomidae) en la Estación de Biología Tropical "Los Tuxtlas", Veracruz. México, UNAM, 204 p (Publicaciones Especiales no. 8)

Cobben RH (1968) Evolutionary trends in Heteroptera. Part I. Eggs, architecture of the shell, gross embryology and eclosion. Centre for Agricultural Publishing and Documentation, Wageningen, $475 \mathrm{p}$

Decoursey RM, Esselbaugh CO (1962) Descriptions of the nymphal stages of some North American Pentatomidae (HemipteraHeteroptera). Ann Entomol Soc Am 55:323-342

Draslar K (1973) Functional properties of trichobothria in the bug Pyrrhocoris apterus (L.). J Comp Physiol 84:175-184

Dyar HG (1890) The number of molts of lepidopterous larvae. Psyche 5:420-422

Froeschner RC (1960) Cydnidae of the western hemisphere. Proc U S Natl Mus 111:337-680

Garcia CA, Bellotti AC (1980) Estudio preliminar de La Biologia y morfologia de Cyrtomenus bergi Froeschner, nueva Praga de la Yuca. Rev Colomb Entomol 6:55-61

Grazia J, Frey-da-Silva A (2001) Descrição dos imaturos de Loxa deducta Walker e Pallantia macunaima Grazia (Heteroptera: Pentatomidae) em ligustro, Ligustrum lucidum Ait. Neotrop Entomol 30:73-80

Grazia J, Schwertner F, Silva EJE (2004) Arranjos taxonômicos e nomenclaturais em Scaptocorini (Hemiptera: Cydnidae, Cephalocteinae). Neotrop Entomol 33:511-512

Haupt J (1970) Beitragzur Kenntnis der Sinnesorgane von Symphylen (Myriapoda).I. Elektronen mikroskopische Untersuchung des Trichobothriums von Scutigerella immaculata Newport. Z Zellforsch 110:588-599

Haupt J (1978) Ultrastruktur der Trichobothrien von Allopauropus (Decapauropus) (Pauropoda). AbhVerh NaturwissVerh 21(22):271277
Keil TA (1997) Functional morphology of insect mechanoreceptors. Microsc Res Tech 39:506-531

Lis JA (1991) Schiodtella secunda n. sp., a new species of burrowing bugs from Palaearctic China (Heteroptera: Cydnidae: Scaptocorinae). Int J Invertebr Taxon - Genus (Wrocaw) 2:27-31

Lis JA, Hohol-Kilinkiewicz A (2001) Abdominal trichobothrial pattern and its taxonomic and phylogenetic significance in Cephalocteinae (Hemiptera: Heteroptera: Cydnidae). Ann Zool (Warszawa) 51:293-297

Martins FS, Campos LA (2006) Morfologia e biologia dos imaturos de Euschistus hansi (Hemiptera, Heteroptera, Pentatomidae). Iheringia Ser Zool 96:213-218

Matesco VC, Fürstenau BBRJ, Bernardes JLC, Schwertner CF, Grazia J (2009) Morphological features of the eggs of Pentatomidae (Hemiptera: Heteroptera). Zootaxa 1984:1-30

Mayorga MC, Cervantes LP (2001) Life cycle and description of a new species of Amnestus dallas (Hemiptera-Heteroptera: Cydnidae) associated with the fruit of several species of ficus (Moraceae) in Mexico. J NY Entomol Soc 109:392-402

Mcdonald FJD (1968) Some observations on Sehirus cinctus (Palisot de Beauvois) (Heteroptera: Cydnidae). Can J Zool 46:855-858

Nardi C, Fernandes PM, Bento JMS (2008) Wing polymorphism and dispersal of Scaptocoris carvalhoi (Hemiptera: Cydnidae). Ann Entomol Soc Am 101:551-557

Parra JRP, Haddad ML (1989) Determinação do número de instar de insetos. FEALQ, Piracicaba, $49 \mathrm{p}$

Paul AR (1953) Life history of the pied shield bug, Sehirus bicolor L. (Hem.: Cydnidae). Ent Mon Mag 89:210-211

Richter PO (1972) Taxonomy of immature insects-present status and future needs. Bull Entomol Soc Am 18:99-101

Sales JRO, Medeiros MO (2001) Percevejo castanho da raiz em pastagens. In: Reunião Sul-Brasileira sobre Pragas de Solo, 8, 2001, Londrina, Anais... Londrina: Embrapa Soja, p 71-79. (Embrapa Soja, Documentos 172)

Schaefer CW (1975) Heteropteran trichobothria (Hemiptera: Heteroptera). Int J Insect Morphol Embryol 4(3):193-264

Schuh RT, Slater JA (1995) True bugs of the world (Hemiptera: Heteroptera). Classification and natural history. Cornell University Press, Ithaca, $x i i+338 p$

Schwertner CF, Albuquerque GS, Grazia J (2002) Descrição dos estágios imaturos de Acrosternum (Chinavia) ubicum Rolston (Heteroptera: Pentatomidae) e efeito do alimento no tamanho e coloração das ninfas. Neotrop Entomol 31:571-579

Sites RW, Mcpherson JE (1982) Life history and laboratory rearing of Sehirus cinctus cinctus (Hemiptera: Cydnidae), with descriptions of immature stages. Ann Entomol Soc Am 75:210-215

Southwood TRE (1949) Some notes on the early stages and biology of Sehirus bicolor (L.) (Hemiptera: Cydnidae). Entomol Mon Mag 85:39-41

Southwood TRE, Hine DJ (1950) Further notes on the biology of Sehirus bicolor (L.) (Hemiptera: Cydnidae). Entomol Mon Mag 86:299-301

Stehr FW (1991) Immature insects. Kendall Hunt, Dubuque, p 975, 2. vol

Stokes HG (1950) The early stages of Sehirus bicolor L. (Hem., Cydnidae). Entomol Mon Mag 89:309-310 